\title{
Plasma renin activity in the management of congenital adrenal hyperplasia
}

\author{
K D GRIFFITHS, J M ANDERSON, B T RUDD, N K VIRDI, G HOLDER, AND \\ P H W RAYNER \\ Department of Clinical Chemistry, Children's Hospital; Institute of Child Health; and Department of Clinical \\ Endocrinology, Women's Hospital, Birmingham
}

SUMMARY Fourteen children with salt losing and five children with non-salt losing congenital adrenal hyperplasia were studied. Venous samples were collected for measurement of plasma renin activity, serum $17 \alpha$-hydroxyprogesterone, testosterone, sodium, and creatinine. Overnight urinary sodium and creatinine excretions were measured after collection on an outpatient basis. Eight 'salt losers' had a raised plasma renin activity despite mineralocorticoid treatment, as did one 'non-salt loser'. Six of the children in whom clinical and biochemical control was inadequate, including the 'non-salt loser', had an increase in the dose of fludrocortisone. When the investigations were repeated one month later, a fall in plasma renin activity accompanied by a fall in $17 \alpha$-hydroxyprogesterone in all but one patient were found. The dose of mineralocorticoid may be as critical as the dose of glucocorticoid in the management of congenital adrenal hyperplasia, and regular determination of plasma renin activity should be made, particularly if clinical control is difficult.

Cortisol, corticosterone, and aldosterone are synthesised from cholesterol by a series of enzymatically controlled steps. A deficiency of one of these enzymes, 21-hydroxylase, is the underlying cause in $90 \%$ of all cases of congenital adrenal hyperplasia. The resultant increase in androgen production will, if untreated, lead to virilisation. In children, Wilkins et al ${ }^{1}$ introduced treatment with cortisone which was aimed at suppressing the production of the excessive androgens.

Up to $50 \%$ of these patients present in the first few weeks of life with a salt losing state that requires urgent mineralocorticoid and glucocorticoid replacement treatment. The adequacy of treatment is monitored by measuring urinary 17-oxosteroid and pregnanetriol excretion or more recently by the measurement of serum 17 $\alpha$-hydroxyprogesterone and testosterone; the latter being peripherally formed from adrenal androgens. ${ }^{2}$ Evaluation of sodium homeostasis also requires continued monitoring as it has been shown that despite adequate glucocorticoid replacement, satisfactory adrenal suppression may be difficult to achieve without adequate mineralocorticoid replacement in salt losing and non-salt losing patients. ${ }^{34}$

This study was designed to assess the value of measuring plasma renin activity in addition to $17 \alpha$-hydroxyprogesterone and testosterone concentrations on an outpatient basis in the long term monitoring of children with congenital adrenal hyperplasia already on treatment with glucocorticoid and mineralocorticoid replacement, and to assess the effects of an alteration in the dosage of mineralocorticoid replacement where indicated.

\section{Patients}

Nineteen patients with congenital adrenal hyperplasia caused by 21-hydroxylase deficiency were studied (Table 1). Height was measured using a Harpenden stadiometer, pubertal development was assessed using the standards of Tanner and Whitehouse ${ }^{5}$ and skeletal maturation by the system of Tanner, Whitehouse and Healey. ${ }^{6}$ Fourteen patients aged 3 to 16 years had an episode of salt loss in the neonatal period. All these children were being treated with glucocorticoid, 11 were taking cortisone, two hydrocortisone, and one prednisolone, given in equal divided dosage twice daily. All except one were also taking fludrocortisone in doses ranging from $25 \mu \mathrm{g}$ to $100 \mu \mathrm{g} /$ day.

The mother of a 3 year old child (case 9) had 
Table 1 Biochemical data on all children in the study

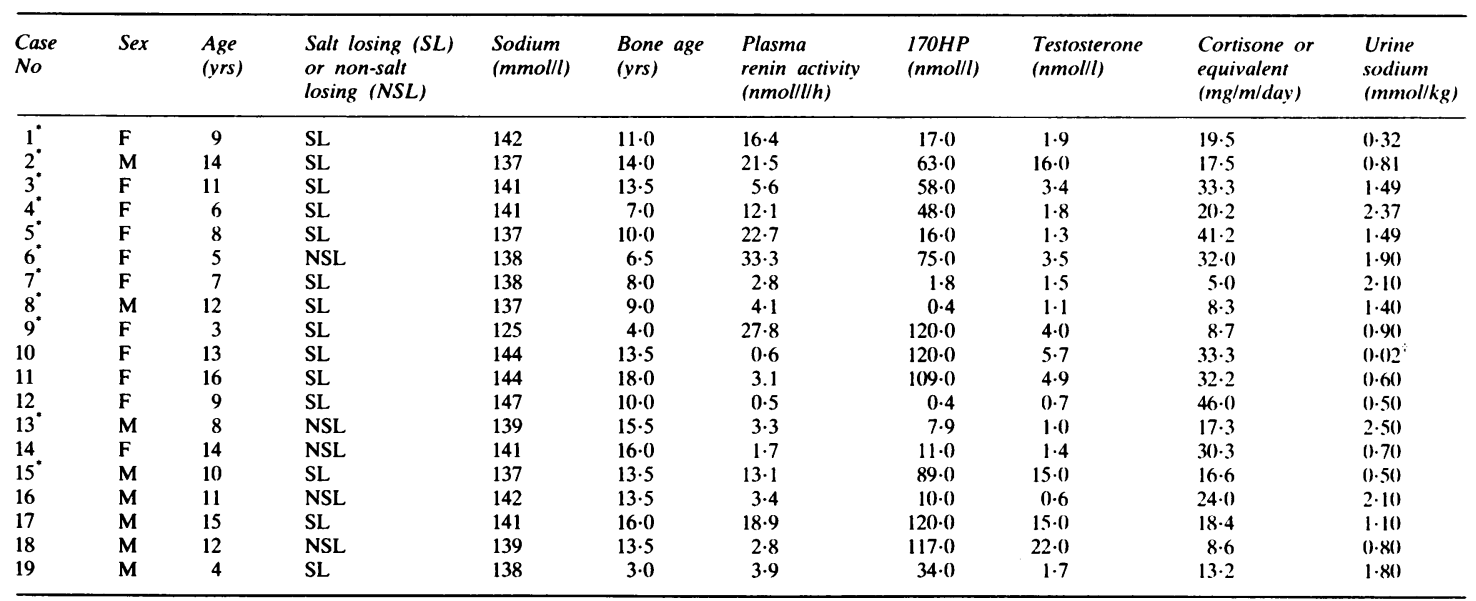

Analyses on these patients were repeated as described in text.

${ }^{+}$Urine collection incomplete.

refused to give her daughter mineralocorticoid after the age of 1 year but she was being maintained on a small dose of cortisone. Five children aged 5 to 14 years had no history of salt loss. Of these, two girls presented with genital virilisation at birth and three boys had precocious puberty. These children were on treatment with glucocorticoid, and one boy (case 2) and one girl (case 6) were taking cyproterone acetate (50 $\mathrm{mg}$ to $100 \mathrm{mg}$ twice daily) (Table 2).

At the time of investigation all the children were well and were receiving a sodium intake of greater than $100 \mathrm{mmol} /$ day. They were all seen in a children's day ward after having had their morning doses of steroid and usual breakfast at home. Each child collected an overnight, timed sample of urine for measurement of sodium and creatinine excretion. After resting in the supine position for two hours, blood obtained by venepuncture was transferred to tubes containing disodium ethylenediamenetetra-acetic acid $(1.2 \mathrm{mg} / \mathrm{ml})$ for plasma renin activity measurement. At the same time blood was also collected for measurement of serum $17 \alpha$-hydroxyprogesterone, testosterone, sodium, and creatinine measurements. The blood collected for plasma renin activity measurement was kept cold in an ice water bath, the plasma was separated at $4^{\circ} \mathrm{C}$, and samples were stored frozen until assayed. In all patients blood was collected between $11.30 \mathrm{am}$ and $12.15 \mathrm{pm}$.

\section{Methods}

Serum $17 \alpha$-hydroxyprogesterone was measured by radioimmunoassay, essentially as described by Davila et al. ${ }^{7}$ The immunogen used to raise the antibody in rabbits was a $17 \alpha$-hydroxyprogesterone-3-(0-carboxymethyl) oxime bovine serum albumin conjugate. Slight modifications to the method were the use of an antibody with reduced cross reactivity for progesterone (less than $1 \cdot 0 \%$ )

Table 2 Clinical details of children in whom fludrocortisone was increased

\begin{tabular}{|c|c|c|c|c|c|c|c|c|}
\hline \multirow[t]{2}{*}{$\begin{array}{l}\text { Case } \\
\text { No }\end{array}$} & \multirow[t]{2}{*}{ Sex } & \multirow[t]{2}{*}{ Age } & \multirow{2}{*}{$\begin{array}{l}\text { Salt losing } \\
(S L) \text { or } \\
\text { non-salt } \\
\text { losing (NSL) }\end{array}$} & \multirow[t]{2}{*}{$\begin{array}{l}\text { Bone age } \\
\text { (yrs) }\end{array}$} & \multirow[t]{2}{*}{$\begin{array}{l}\text { Growth (centiles) } \\
\text { (Tanner \& Whitehouse) }\end{array}$} & \multirow[t]{2}{*}{$\begin{array}{l}\text { Sexual } \\
\text { development }\end{array}$} & \multicolumn{2}{|c|}{$\begin{array}{l}\text { Fludrocortisone } \\
\text { (mg/day) }\end{array}$} \\
\hline & & & & & & & $\begin{array}{l}\text { Before } \\
\text { adjustment }\end{array}$ & $\begin{array}{l}\text { After } \\
\text { adjustment }\end{array}$ \\
\hline 1. & $\mathbf{F}$ & 9 & SL & 11 & $75-90$ & PH2 B1 & 0.025 & $0 \cdot 10$ \\
\hline $2^{*}$ & $\mathbf{M}$ & 14 & SL & 14 & $25-50$ & PH3 G4 & $0 \cdot 1$ & 0.15 \\
\hline 3 & $\mathbf{F}$ & 11 & SL & $13 \cdot 5$ & $75-90$ & PH3 B2 & $0 \cdot 1$ & 0.15 \\
\hline 4 & $\mathbf{F}$ & 6 & SL & 7 & $3-10$ & $\mathrm{PH} 2 \mathrm{~B} 1$ & $0 \cdot 05$ & 0.10 \\
\hline 5 & $\mathbf{F}$ & 8 & SL & 10 & $50-75$ & $\mathrm{PH} 2 \mathrm{~B} 2$ & $0 \cdot 1$ & 0.15 \\
\hline $6^{\circ}$ & $\mathbf{F}$ & 5 & NSL & $61 / 2$ & 75 & PH2 B1 & $\mathrm{Nil}$ & 0.025 \\
\hline
\end{tabular}

$\mathrm{PH}=$ pubic hair, $\mathrm{B}=$ breast development.

On cyproterone acetate. 
and substitution of phosphate buffer for Tris buffer. Reference intervals obtained with this method were unchanged from those reported by Davila et al. ${ }^{7}$ Serum testosterone was measured by a similar radioimmunoassay using an antibody prepared from a testosterone-3-(0-carboxymethyl) oxime conjugate and raised in sheep. This antibody was generously supplied by Professor V Marks (SAS Centre, Guildford).

Plasma renin activity was determined using a kit (Angiotensin I radio-immunoassay kit, CIS UK) which measured the angiotensin I generated when plasma was incubated at $37^{\circ} \mathrm{C}$ in the presence of inhibitors of converting enzyme (which converts angiotensin I to angiotensin II) and angiotensinases. Single end point determinations may give falsely low values in cases of substrate exhaustion and so angiotensin I was routinely measured in aliquots of the incubation mixture at regular timed intervals. Plasma renin activity was also measured under identical conditions and at the same time of day in four healthy children with no evidence of renal or endocrine abnormality.

The adequacy of previous steroid dosage was assessed by reviewing clinical records of growth, bone age, and sexual development over the previous two years. Using these criteria 9 children were considered to be well controlled and 7 under treated. Treatment could not be fully assessed in three boys with pubertal testicular development.

Eleven children were recalled and the investigations repeated under identical conditions without change in steroid treatment. In five children with a history of early salt loss and an appreciably raised plasma renin activity ${ }^{8}$ of greater than $5 \mathrm{nmol} / \mathrm{l} / \mathrm{hour}$ on two occasions, the dose of fludrocortisone was increased by $50 \mu \mathrm{g} / \mathrm{day}$. One prepubertal girl with no history of salt loss but a raised plasma renin activity and clinical evidence of inadequate treatment, was started on $50 \mu \mathrm{g} /$ day of fludrocortisone. Investigations in the six children whose dose of fludrocortisone had been increased were repeated three or four weeks later.

\section{Results}

Serum sodium concentrations were within the reference interval 134 to $145 \mathrm{mmol} / \mathrm{l}$ in 17 of the 19 patients (Table 1). The one child whose mother had refused treatment with mineralocorticoid had a serum sodium value of $125 \mathrm{mmol} / \mathrm{l}$ and another who had been vomiting the day before had a value of 133 $\mathrm{mmol} / \mathrm{l}$. Urinary sodium excretion, as might have been expected because of the high dietary salt intake, was increased above the reference interval of 0.08 to $0.16 \mathrm{mmol} / \mathrm{kg}$ body weight in all children studied except one, for whom urine collection was incomplete, and there was no statistical difference between 'salt losers' and 'non-salt losers' $(P<0 \cdot 4)$. In four of the 6 children in whom the dose of fludrocortisone was increased a fall in sodium occurred, with a slight increase in the remaining two. Creatinine clearance was within reference intervals for 15 of the children studied, ${ }^{9}$ in three children the urine collections were incomplete, and in one patient (case 9) we have no adequate explanation for reduced clearance.

Plasma renin activity in four apparently healthy children aged 8 to 16 years with no evidence of renal or endocrine disease, was $1.3,2.4,2.7$, and 3.5 $\mathrm{nmol} / \mathrm{l} / \mathrm{hour}$. The results in the congenital adrenal hyperplasia patients are shown in Table 1 and graphically depicted in Fig. 1. Nine of the children with congenital adrenal hyperplasia had plasma renin activity values of greater than $5 \cdot 0 \mathrm{nmol} / \mathrm{l} / \mathrm{hour}$ and only one of these was a 'non-salt loser'. Plasma renin activity in the 'salt losers' ranged from 0.5 to 27.8 (mean 10.9) nmol///hour. After increasing the dose of fludrocortisone in the 6 children there was a statistically significant drop in plasma renin activity $(P<0.02)$ in all including the one child who had no early history of salt loss (Fig. 2).

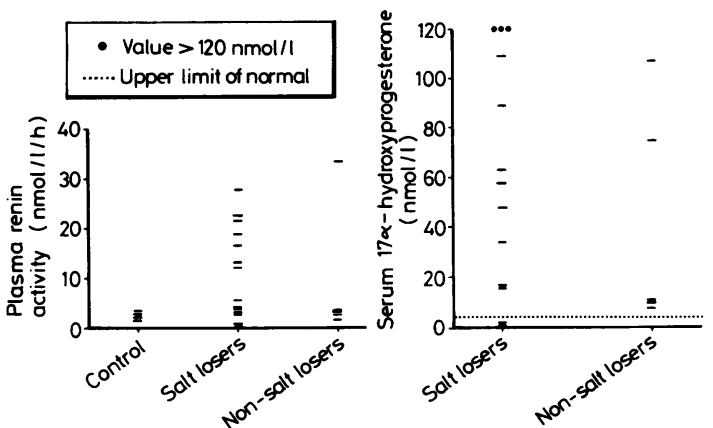

Fig. 1 Plasma renin activity and $17 \alpha$-hydroxyprogesterone values in congenital adrenal hyperplasia.
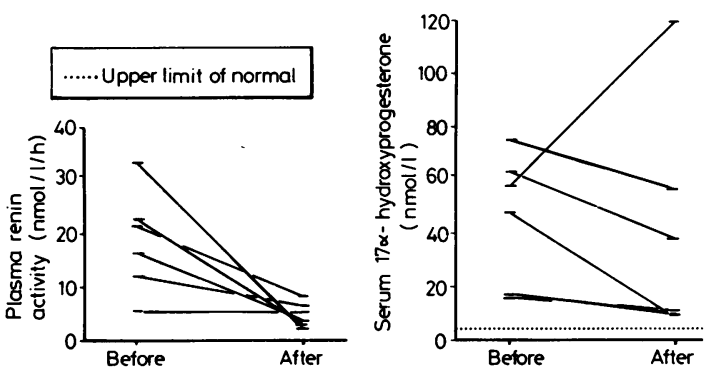

Fig. 2 Plasma renin activity and $17 \alpha$-hydroxyprogesterone values before and after an increase in mineralocorticoid dosage in 6 patients. 
Blood samples for $17 \alpha$-hydroxyprogesterone were taken at the same time of day on all occasions in an attempt to minimise the effect of circadian rhythms. ${ }^{1011}$ Sixteen of 19 patients had abnormal values varying from $7.9 \mathrm{nmol} / 1$ to greater than 120 $\mathrm{nmol} / \mathrm{l}$ on their first visit (reference interval 0.4 to $4 \cdot 2 \mathrm{nmol} / \mathrm{l})^{7}$. For practical purposes a value of 12 $\mathrm{mmol} / \mathrm{l}$ was taken as the upper level of satisfactory clinical control. Of the 11 patients recalled 9 still had abnormally high concentrations. Four children with normal plasma renin activity values had a noticeably raised $17 \alpha$-hydroxyprogesterone value while in only three children were both $17 \alpha$-hydroxyprogesterone and plasma renin activity values normal. These variations indicate the difficulty in interpretation, even when sampling time is standardised. No child with raised plasma renin activity values had a normal 17 $\alpha$-hydroxyprogesterone concentration. In 7 patients considered to be satisfactorily controlled on clinical grounds, serum 17 $\alpha$-hydroxyprogesterone values varied from 0.4 to greater than $120 \mathrm{nmol} / \mathrm{l}$. In 7 patients considered inadequately controlled serum $17 \alpha$-hydroxyprogesterone values varied from 11 to greater than $120 \mathrm{nmol} / \mathrm{l}$ (mean $58.4 \mathrm{nmol} / \mathrm{l}$ ), and values between 10 and greater than $120 \mathrm{nmol} / \mathrm{l}$ were obtained in patients in whom treatment could not be fully assessed on clinical grounds.

After increasing the dose of fludrocortisone in 6 patients, serum $17 \alpha$-hydroxyprogesterone values fell in five (Table 3). The one child (case 3) who had the lowest plasma renin activity value (Fig. 2) had a rise in $17 \alpha$-hydroxyprogesterone which was also accompanied by a rise in serum testosterone. Noncompliance with treatment as an explanation for this finding was denied by the parents.

Serum testosterone was within the reference interval of 0.2 to $3.2 \mathrm{nmol} / 1(\mathrm{n}=29)$ established for hospitalised boys and girls without endocrine disease (aged 5 to 15 years, pubertal stage I and II). Those within normal values had 17 $\alpha$-hydroxyprogesterone values which were either normal for children (less than $4.2 \mathrm{nmol} / \mathrm{l}$ ) or raised into the normal adult female range (up to $16 \cdot 0 \mathrm{nmol} / \mathrm{l}$ ). Of the other 9 children, 7 were considered to be well controlled by clinical assessment. In 7 children showing no pubertal development, serum testosterone ranged from 1.0 to $15.0 \mathrm{nmol} / \mathrm{l}$ (mean 3.7 $\mathrm{nmol} / \mathrm{l})$. Serum testosterone concentrations when compared with $17 \alpha$-hydroxyprogesterone showed a correlation only for the prepubertal children $(n=9$, $r=0.943, P=0.05$ to 0.02 ). Increasing the dose of fludrocortisone had no consistent effect on serum testosterone.

Blood pressure in all children studied was normal at all times, and there was no alteration in salt appetite.

Table 3 Serum $17 \alpha$-hydroxyprogesterone, testosterone, and plasma renin activity values before and after adjustment in fludrocortisone treatment in 6 children (five salt losers and one non-salt loser)

\begin{tabular}{|c|c|c|c|c|c|}
\hline $\begin{array}{l}\text { Case } \\
\text { No }\end{array}$ & $\begin{array}{l}\text { Age } \\
\text { (years) }\end{array}$ & $\begin{array}{l}\text { Months heforel } \\
\text { after adjusted } \\
\text { treatment }\end{array}$ & $\begin{array}{l}\text { I7a-hydroxyprogesterone } \\
\text { (nmol/l) }\end{array}$ & $\begin{array}{l}\text { Testosterone } \\
\text { (nmollll) }\end{array}$ & $\begin{array}{l}\text { Plasma renin } \\
\text { activity } \\
\text { (nmoll/lhour) }\end{array}$ \\
\hline 3 & 11 & $\left\{\begin{array}{r}-2 \\
0 \\
+2 \\
+5\end{array}\right.$ & $\begin{array}{r}58.0 \\
18.0 \\
12(1) \cdot 0 \\
88.0\end{array}$ & $\begin{array}{l}3 \cdot 4 \\
1 \cdot 6 \\
4 \cdot 5 \\
4 \cdot 6\end{array}$ & $\begin{array}{l}5 \cdot 6 \\
5 \cdot 5 \\
5 \cdot 3 \\
-\end{array}$ \\
\hline 5 & 8 & $\left\{\begin{array}{r}-2 \\
0 \\
+2\end{array}\right.$ & $\begin{array}{l}16 \cdot 0 \\
12 \cdot() \\
11 \cdot 0\end{array}$ & $\begin{array}{l}1 \cdot 3 \\
3 \cdot 6 \\
1 \cdot 0\end{array}$ & $\begin{array}{r}22 \cdot 7 \\
6.9 \\
2.9\end{array}$ \\
\hline 4 & 6 & $\left\{\begin{array}{r}-2 \\
0 \\
+2\end{array}\right.$ & $\begin{array}{l}48 \cdot 0 \\
27 \cdot 0 \\
10 \cdot 0\end{array}$ & $\begin{array}{l}1.8 \\
1.6 \\
1.5\end{array}$ & $\begin{array}{r}12 \cdot 1 \\
35 \cdot 2 \\
6 \cdot 5\end{array}$ \\
\hline 6 & 5 & $\left\{\begin{array}{r}0 \\
+1 \\
+3 \\
+6\end{array}\right.$ & $\begin{array}{r}75.0 \\
57 \cdot 0 \\
-\quad 40.0\end{array}$ & $\begin{array}{l}3.5 \\
3.7 \\
2.7 \\
1.5\end{array}$ & $\begin{array}{c}33 \cdot 3^{\circ} \\
2 \cdot 4^{\circ} \\
-\end{array}$ \\
\hline 1 & 9 & $\left\{\begin{array}{r}-2 \\
0 \\
+1 \\
+4\end{array}\right.$ & $\begin{array}{r}17 \cdot 0 \\
79 \cdot 0 \\
9 \cdot 8 \\
66 \cdot 0\end{array}$ & $\begin{array}{l}1.9 \\
3.2 \\
1.4 \\
4 \cdot 1\end{array}$ & $\begin{array}{c}16 \cdot 4 \\
181 \cdot 0 \\
3.7 \\
-\end{array}$ \\
\hline 2 & 14 & $\left\{\begin{array}{r}-2 \\
0 \\
+1\end{array}\right.$ & $\begin{array}{l}63 \cdot 0 \\
96 \cdot 0 \\
38 \cdot 0\end{array}$ & $\begin{array}{l}16 \cdot 0 \\
17 \cdot 0 \\
28 \cdot 0\end{array}$ & $\begin{array}{r}21 \cdot 5 \\
14 \cdot 5 \\
8 \cdot 3\end{array}$ \\
\hline
\end{tabular}

On $9 \alpha$ fludrocortisone $0.25 \mathrm{mg} /$ day. "On $9 \alpha$ fludrocortisone $0.05 \mathrm{mg} / \mathrm{day}$. 


\section{Discussion}

In 1963 Cara and Gardener ${ }^{12}$ detected hyperplasia of the juxtaglomerular cells in a 4 year old girl with salt losing congenital adrenal hyperplasia, and suggested compensatory hyperplasia of the renin angiotensin system in response to chronic sodium loss. Imai et $a l^{13}$ reported raised plasma renin activity values in two cases of salt losing congenital adrenal hyperplasia, and showed that it was reduced after treatment with desoxycorticosterone and salt supplements.

It is well known that children who have a neonatal salt losing crisis due to 21-hydroxylase deficiency continue to have a salt losing state unless treatment with mineralocorticoid is maintained. This is reflected in the high plasma renin activity values found in children who have stopped mineralocorticoid in later childhood. ${ }^{414}$ It is now recognised that treatment with mineralocorticoid should be continued indefinitely, for although stopping this may not produce a salt losing crisis in older children, it may be more difficult to achieve adequate adrenal suppression even with large doses of glucocorticoid. ${ }^{3} 15$

The mechanism by which adequate mineralocorticoid in addition to glucocorticoid allows better control in children with 21-hydroxylase deficiency is not well understood. Schaism et a ${ }^{16}$ by infusing angiotensin II into patients with congenital adrenal hyperplasia due to 21-hydroxylase deficiency, showed an increase in aldosterone and $17 \alpha$-hydroxyprogesterone values without any change in plasma adrenocorticotrophic hormone values, suggesting that angiotensin II had a direct effect on adrenal steroidogenesis by increasing the enzyme block. In the present study we have found that plasma renin activity values may be raised in children who have never had a clinical salt losing episode (case 6), which confirms other reports ${ }^{15} 17$ and suggests salt homeostasis is impaired, although to a lesser degree than in salt losers.

This would lend support to the theory that there is no distinct dividing line between 'salt losers' and 'non-salt losers'. The present study shows that despite continuing fludrocortisone through childhood, the dose of this is critical. 17 $\alpha$-hydroxyprogesterone cannot be fully suppressed in salt depleted children with glucocorticoids alone and the quantity of fludrocortisone added to the treatment regimen may be as critical as the dose of cortisone in achieving adrenal suppression.

All of the children investigated had a high sodium clearance and 16 had raised 17 $\alpha$-hydroxyprogesterone values. These findings included both 'salt losers' and 'non-salt losers' suggesting that cortisol precursors have a naturetic effect ${ }^{18} 19$ and that this naturesis was not appreciably changed by increasing the dose of fludrocortisone. Out of 11 patients retested, 9 still had raised $17 \alpha$-hydroxyprogesterone values without change in treatment, showing that this is a useful measurement in monitoring patients and defining those in poor control, provided that the measurements are made with reference to the last dose of glucocorticoid and at the same time of day. ${ }^{1011}$

Increasing the dose of fludrocortisone in those children with a raised plasma renin activity and $17 \alpha$-hydroxyprogesterone concentration, generally produced a fall in both, indicating better control. In one child with only a slightly raised plasma renin activity (case 3 ) there was no significant change after the increased dose, but the 17a-hydroxyprogesterone value increased significantly, as did the testosterone. Non-compliance with treatment was denied. Plasma renin activity values showed a good relative fall by raising the dose of fludrocortisone even though there was no change in salt appetite or consistent reduction in urinary sodium clearance.

This study suggests that the dose of mineralocorticoid may be as critical as the dose of glucocorticoid for the optimum control of patients with congenital adrenal hyperplasia. The dose of fludrocortisone used is unlikely to have an appreciable glucocorticoid effect. The measurement of plasma renin activity seems to be clinically useful as an index of the adequacy of fludrocortisone treatment, and for the detection of further 21-hydroxylase inhibition which may be exacerbated by raised angiotensin values. Further plasma renin activity measurements permit the dose of glucocorticoid to be reduced when excessive amounts are used to normalise $17 \alpha$-hydroxyprogesterone concentrations to regain biochemical and clinical control. There are, however, limitations to its use in day case patients because of the strict condition of rest necessary for adequate measurement of plasma renin activity, which if not adhered to may give misleadingly high values.

We thank Professor W Butt, in whose department some of this work was done; Sister L Styles who organised the specimen collections; Mr H Patel for assistance with plasma renin activity assays; and Miss G Chester and Mrs E Green for typing the manuscript.

\footnotetext{
References

1 Wilkins L, Lewis RA, Klein R, Rosenberg E. Suppression of androgen secretion by cortisone in a case of congenital adrenal hyperplasia, by preliminary report. Bull Johns Hopkins Hosp 1950;86:249-252.

2 Hughes IA, Winter JSD. The application of serum 17hydroxyprogesterone radioimmunoassay to the diagnosis and management of congenital adrenal hyperplasia. J Pediatr 1976;88:766-773.
} 
${ }^{3}$ Hughes IA, Wilton A, Lole CA, Gray OP. Continuing the need for mineralocorticoid therapy in salt-losing congenital adrenal hyperplasia. Arch Dis Child 1979:54:350-5.

${ }^{4}$ Horner JM, Hintz RL, Leutscher JA. The role of renin and angiotensin in salt losing 21-hydroxylase deficient congenital adrenal hyperplasia. J Clin Endocrinol Metab 1979;48:776-83.

5 Tanner JM, Whitehouse RH. Clinical longitudinal standards for height, weight, height velocity, weight velocity and the stages of puberty. Arch Dis Child 197651:170-9.

- Tanner JM, Whitehouse RH, Healey MJR. A new system for estimating skeletal maturity from hand and wrist radiographs. Paris: Centre International de l'enfance, 1962.

7 Davila N, Rudd BT, Morris R, Kardell F, Bodden J, London DR. A simple procedure for radioimmunoassay of 17-alpha-hydroxyprogesterone in serum; comparison with an immunological purification technique. Ann Clin Biochem 1980;17:31-7.

${ }^{8}$ Broughton Pipkin F, Smales PRC, O'Gallaghan M. Renin and angiotensin levels in children. Arch Dis Child 1981;56:298-302.

${ }^{9}$ Insley J, Wood BA. A paediatric Vade-Mecum. Lloyd-Luke, 1982:184.

10 Atherden SM, Barnes ND, Grant DB. Circadian variation in plasma 17-hydroxyprogesterone in patients with congenital adrenal hyperplasia. Arch Dis Child 1972:47:602-4.

11 Frisch H, Parth K, Schober E, Schober W. Circadian patterns of plasma cortisol, 17-hydroxyprogesterone and testosterone in congenital adrenal hyperplasia. Arch Dis Child 1981:56:208-13.

12 Cara J, Gardener LI. The juxtaglomerular cells of the kidney and zona glomerulosa of the adrenal cortex in the sodium-losing and the hypertension forms of virilising adrenal hyperplasia. Pediatrics 1963;32:825-40.
13 Imai M, Igarashi Y, Sokabe H. Plasma renin activity in congenital virilising adrenal hyperplasia. Pediatrics 1968;41: 897-904.

14 Rosler A, Levine LS, Schneider B, Norogroder M, New MI. The inter-relationship of sodium balance, plasma renin activity and ACTH in congenital adrenal hyperplasia. Pediatrics 1968;41:897-904.

15 Grant, DB, Dillon MJ, Atherden SM, Levinsky RJ. Congenital adrenal hyperplasia. Renin and steroid values during treatment. Eur J Pediatr 1977;126:89-96.

${ }^{16}$ Schaism G, Conzinet B, Gourmelen M, Elkik F, Bourgneres P. Angiotensin and adrenal steroidgenesis: Study of 21-hydroxylase deficient congenital adrenal hyperplasia. J Clin Endocrinol Metab 1980;50:1390-4.

17 Strickland AL, Kotchen TA. A study of the renin-aldosterone system in congenital adrenal hyperplasia. J Pediatr 1972;81: 962-9.

18 Jacobs DR. Poll JVD, Gabrielove JL, Soffer LJ. 17-alpha-hydroxyprogesterone-a salt losing steroid; relation to congenital adrenal hyperplasia. J Clin Endocrinol Metab 1961:21:909-22.

19 Landon RL, Lugibihl K. Inhibition of the sodium retaining influence of aldosterone by progesterone. J Clin Endocrinol Metab 1958;81:1237-45.

Correspondence to $\operatorname{Dr}$ K D Griffiths, Department of Clinical Chemistry, The Children's Hospital, Ladywood Middleway, Ladywood. Birmingham B16 8ET.

Received 10 January 1984 